\title{
Consumer Protection on Telecommunication Services Prepaid Card in Indonesia: The Complicated Condition on Laws and Practices
}

\author{
Muhammad Afifudin Aziz ${ }^{1 \mathrm{a}}$, Nurul Fibrianti ${ }^{1 \mathrm{~b}}$ \\ ${ }^{1}$ Faculty of Law, Universitas Negeri Semarang (UNNES), Indonesia \\ a afifudin.aziz@gmail.com, ${ }^{\mathrm{b}}$ nurulfibrianti@mail.unnes.ac.id
}

\begin{abstract}
The result of this research indicates that the use of personal data by the Telecommunication Services Provider has been through procedures in accordance with the provisions of Regulation the Population Administration Act and the Regulation of the Minister of Internal Affairs Number 61 of 2015; The result of the research are (1)Telecommunication Provider defaulted the consumer's rights which guaranteed in Consumer Protection Regulation, when consumer asked complaint against misuse of a prepaid simcard; (2)There is no mechanism of prepaid consumer protection implemented after the regulation which should be done by the government and telecommunication service providers; (3)The regulation is legal defect, because none of simcard which blocked by service providers when the consumer won't do register or reregister using NIK and KK, then The Internet simcard did not pass the registration process, which meant someone vulnerable do abuse of SMS or phone and undetectable who own it. From the research results it could be concluded (1) There is no real form of consumer when someone misuse of prepaid sim card as spoken by Mr. Rudiantara which stated in the regulation. Even the Telecommunication provider had seized the rights of comfort and to be secure which guaranteed in Regulation of Consumer Protection Number 8 Of 1999, furthermore they did wanprestasi by broke the terms of the agreement in the standard clause which any consumers won't read them. (2)There is no protection mechanism against prepaid consumers who had their prepaid sim card done registered and validated by governments and telecommunications service providers.
\end{abstract}

Keywords_-Prepaid simcard registration; Telecommunication Services; Consumer Protection

\section{INTRODUCTION}

The development of information technology causes a major impact on daily activities, especially in the field of telecommunications. Telecommunication Providers in Indonesia have a huge market. Starter pack for prepaid simcard is one of the tools. The starter pack is a card used by telecommunication service customers to be able to use postpaid or prepaid telecommunications services. The number of communication media, making Telecommunication Service Providers in Indonesia racing to offer the tools to start a communication with a variety of 'package' interesting, ranging from free calls, free sms, to internet quota abundant with a very cheap price.

The Starter Card (in after referred to as Simcard) must have an identity, namely Mobile Subscriber Integrated Services Digital Network (MSISDN). MSISDN number is a number that uniquely identifies customers on mobile cellular networks. With the identity of Sim card in the form of a series of digits as the number MSISDN, consumers can do several things, such as making calls and receiving calls, sending and receiving sms and connected to the internet. The presence of Regulation of the Minister of Communications and Information No. 14 of 2017 makes fresh air for prepaid consumers. This became the counterpart of the Consumer Protection Act in protecting consumers of prepaid sim card telecommunication services.

Reference [1] argues that the consumer's position is weak; it should be protected by law. One of the character, as well as the purpose of the law is to provide protection to the community. Government with the latest regulation , requiring all prepaid subscribers to register Sim card using NIK and KK Numbers in an effort to protect the public from fraud, crime and law violations, as well as to support online transactions. The policy was also welcomed by prepaid subscribers in Indonesia, with 72,500,000 subscribers on 23 November 2017 registering sim card prepaid. But the implementation caused new problems, such as:

1. The misuse of NIK and KK for crime or registration purpose;

2. There is no mechanism of consumer protection, who had done registered and validated phone numbers using NIK and KK.

In the Public Information Disclosure Act, the presence of regulations the use of prepaid sim card registration formats using NIK and KK, becomes a matter that has otherwise been excluded. Ironically, neither the researchers nor the public know how the role of the government and the providers of Telecommunication Service undertake preventive and / or action against the misuse of Sim card, especially those who have registered using NIK and KK Numbers and how to protect prepaid 
consumers. Based on identification and restriction of the above problems, the Authors formulate the problems as follows:

1. How is the consumer protection of telecommunication services that have registered and validated Sim card after Regulation of the Minister of Communication and Information Technology Number 14 year 2017 ?

2. What is the role of government and Telecommunication Service Providers in conducting preventive and / or action steps against misuse of prepaid Sim card?

\section{RESEARCH METHOD}

The research method used is the type of qualitative research with empirical juridical approach. The type of data used in this study is the primary data, interviews and observations obtained directly from the implementation of Regulation of the Minister of Communication and Information No. 14 of 2017, and secondary data in the form of literature, legislation and documentation. The author uses the source triangulation technique to check the validity of data in this research. Triangulation data check technique according to [2], is a technique that attempts to get accurate data by comparing one data to another to check for data relevance. The triangulation data check technique used can be done by: (1) Comparing observational data with interview data; (2). Compare what people say in public with what they say personally; (3) Compare what people are saying about the research situation with what he says all the time;(4) Compare the situation and perspective of a person with the opinions and views of people like ordinary people, middle- and higheducated people, people who are, people of government; (5) Comparing interview results with the contents of a related document [2]. Data processing in this research is done in four stages: Data collection, Data reduction, Data presentation; and Withdrawal of conclusions or verification.

\section{RESULT AND DISCUSSION}

In the regulation, the government puts great attention to the widespread misuse of prepaid sim card which is related to Regulation of Consumer Protection. Through regulation, the government made the registration policy prepaid simcard with how to register using NIK number and KK. However, in the implementation, the public is still presented with the news that the use of personal data is an unnecessary thing, because it can lead to burglary banking accounts, and it is feared the data leaked on the side of government and telecommunications service providers. The following is the substance of the laws which governing personal data:

Law Number 8 of 2014 concerning to Public Information Transparency (KIP), Article 17 letter (h) explains that Public Information when opened and provided to the Public Information Applicant may reveal personal secrets. The data themselves are: (1) Family members' history and condition; (2) History, condition and care, physical and psychological treatment of a person; (3) The financial condition, assets, income, and bank account of a person; (4) Evaluation results relating to the capability, intellect, and recommendations of one's ability; and / or ; (5) Records concerning a person's personalities relating to the activities of the formal education unit and the non-formal education unit.

Article 18 describes matters excluding excluded information as referred to in Article 17 (g) and (h), among others: (1) The party whose secrets are disclosed gives written consent; and / or; (2) Disclosure relates to a person's position in public positions.

Law Number 24 of 2013 on Population Administration, Article 84 explains that personal data to be protected is information about physical and / or mental defects, fingerprints, iris, signatures, and other data elements that constitute a person's disgrace. Article 86 paragraphs (1) describe the Minister as the person in charge of granting the right of access of Personal Data to provincial officers and Officers of Implementing Agencies. Officers are prohibited to disseminate Personal Data that is not in accordance with their authority. Regulation of the Minister of Internal Affairs Number 61 of 2015 on the requirements, scope and procedure of granting access rights and utilization of residence parent numbers, residence data and electronic identity cards. Article 7 Paragraph (1) The Minister of Internal Affairs grants permission for the right to access the population data to the Provincial Officials and the implementing agency officers and users. Article 7 Paragraph (2) the granting of access rights as referred to in paragraph (1) shall be delegated to: Director General of Population and Civil Registration regarding the right of access to officers within the scope of Directorate General of Population and Civil Registration and user institutions at the central level; Governor concerning access rights to officers at Provincial Providers and user institutions at the provincial level; Regent / mayor concerning access rights to officers at District / Municipal Implementing Agencies and district / municipality user institutions.

Authors examine through the review of applicable regulations on how to use, and / or have access rights in the use of personal data. In a research by the researchers, the government has signed a Cooperation Agreement (PKS) as a follow up of a Memorandum of Understanding (MoU) between Ministry of Internal Affairs and Ministry of Communication and Informatic No. 471.12 / 300 / SJ and Number 32 / M.KOMINFO / HK.03.02 / 01 / 2013 on the cooperation of the utilization of Population Identification Number (NIK), Population Data and Electronic Identity Card in the Communication and Informatics Service, which was held on January 29, 2013. In addition, in response to public unrest, the government has granted ISO 27001 certification as a security standard in managing customer data information to 
telecommunication service providers.

The existence of prepaid registration regulation using NIK and KK Numbers actually raises several new problems. Issues that arise include: Registration, when on November 1st 2017 to December 2017, consumers can do a random data for a registration purpose, such as name, address, etc;
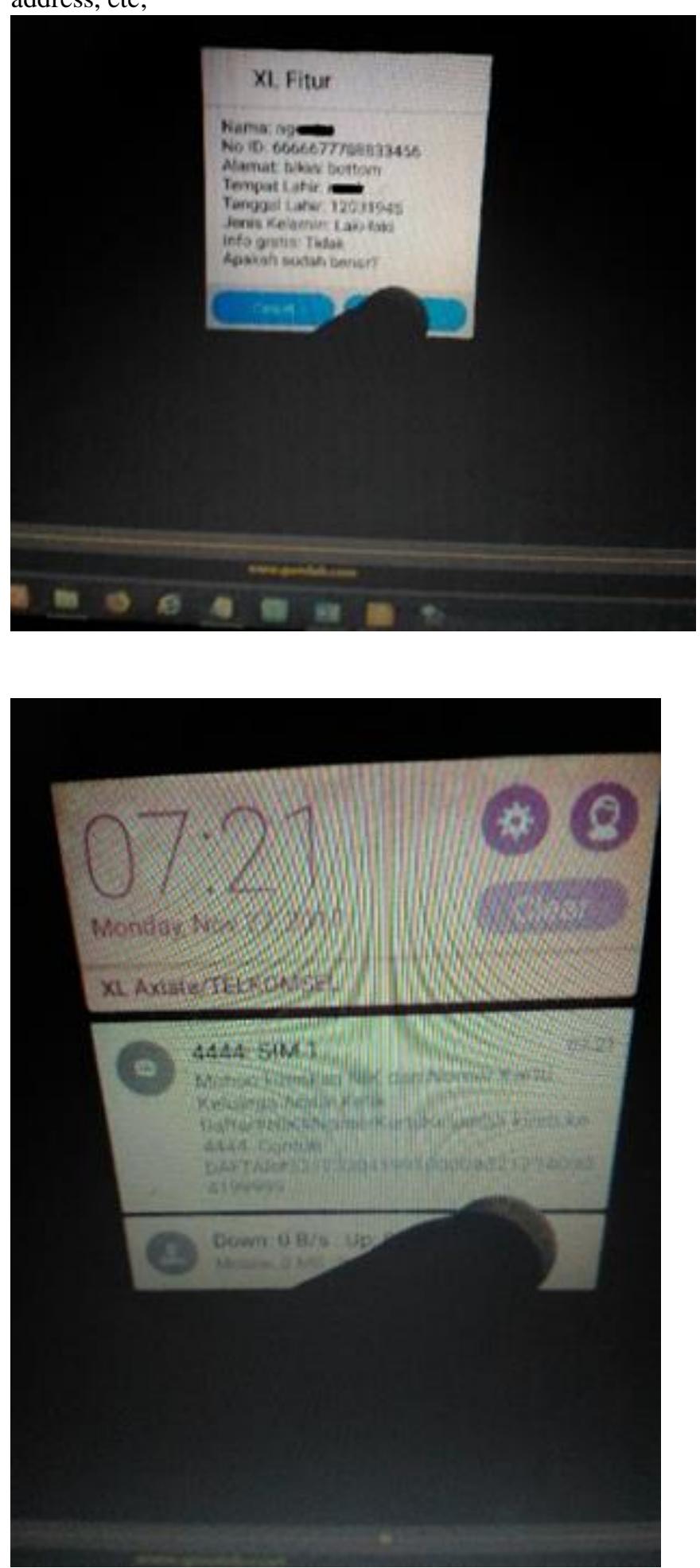

Fig. 1. Random Registration

November 2017 to April 3rd 2018, none of telephone and sms services is blocked by Telecommunication
Providers. In the Regulation of the Minister of Communication and Information No 14 year 2017 on Article 16, the period of blocking is one month after the regulation enacted, and the Internet simcard sold in activated mode without registration-(the validation of consumer data ) which should causes vulnerable abused; March 26th 2018, there is a registration process with the option of entering the name of consumers' Mother;

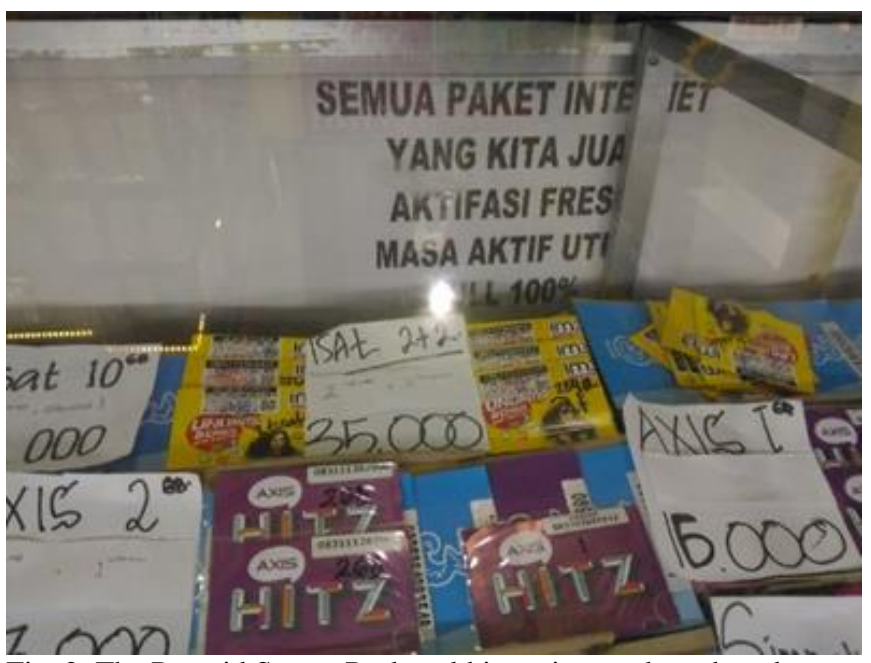

Fig. 2. The Prepaid Starter Pack, sold in active mode and ready to use

Authors find outlets that have special ways and cards for activation purposes, even those provided by Telecommunication Providers to perform simcard activation without going through registration and validation processes that impact the simcard directly can be used properly; Data Abuse, there is a person of Semarang abusing NIK and KK data, but there is no effort to act on it; 


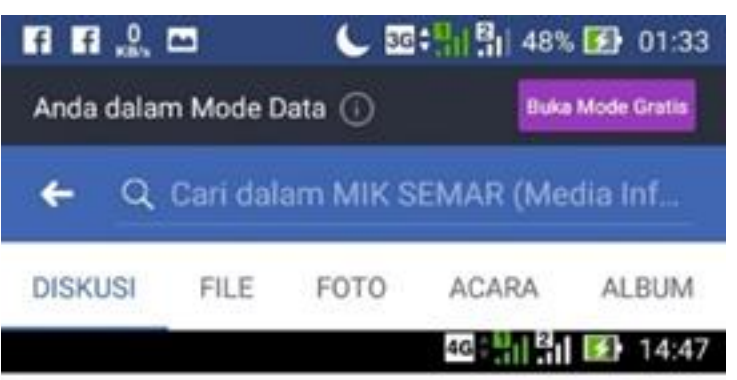

\section{A mobile.facebook.com/story.php?stor C :}

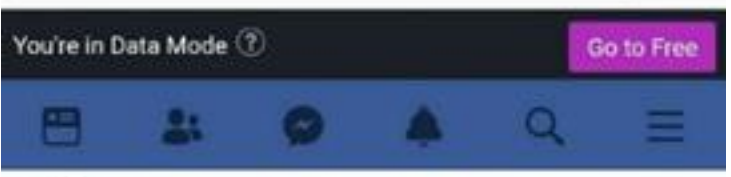

\section{Linda Ferdiana}

3 hrs - Facebook for Android - id

\section{cerita pagi ini;}

ada orang beli kartu perdana + bawa kartu keluarga

utk sekalian diregistrasi. pas buka KK kok familiar nama2nya, ternyata KK punya bapakku dewe. Iho piye to iki kok KKne iso digowo wong, tak takoni entuk seko ndi bilange seko kantor. timbang bali jupuk neng omah aku teko jupuk neng kantor jaree.. jebule wong e kerjo neng kecamatan. nyuwun sewu pak njenengan tak seneni.. nyuwun tulung ditindaklanjuti bu Dian Novita Sari. jangan sampai data orang lain disalahgunakan $\Theta$

0 Like $\quad \square$ comment $\quad \Rightarrow$ Share

Fig. 3. Data Abuse

There's no action to take down site on the Internet and arrest the people which published NIK and KK Numbers illegally; Regulation of Regulation of the Minister of Communication and Information Technology Number 14 of 2017 Legal defects; Regulatory regulation does not have adequate legal certainty. There is no mechanism of consumer protections who was a victim of misuse of a prepaid simcard. Regulation of Minister of Communications and Information Technology Regulation No. 21 of 2017. Legal defects; Registration Format is still showing an option for filling the mother's name. Provider of Telecommunication Service, and There is no attempt to protect its customers as victims of misconduct of prepaid simcard; The telecommunications provider did a wanprestasi, stated they were not authorized to block simcard services unilaterally, even if a prepaid consumers perform various forms misuse of prepaid simcard; The complainant support service is not working properly.

\section{CONCLUSION}

There is no real act of consumer protection against any abused of using prepaid simcard by the government and the Telecommunication Providers. There is no conformity with the statement of the Minister of Communications and Information and Technology that Prepaid registration is a concrete form of government in protecting telecommuni-cation service customers. In fact, the Telecommunication Service Provider did wanprestasi and depriving the right of consumers which guaranteed in Regulation of Consumer Protection No. 8 of 1999. There are no prepaid consumer protection mechanism that have registered and simulated prepaid sim card by the government or the telecommunication provider.

\section{REFERENCES}

[1] Shidarta.Hukum Perlindungan Konsumen Indonesia. Jakarta: Grasindo, 2004

[2] Moleong, J. Lexy. Metode Penelitian Kualitatif. Bandung: Remaja Rosdakarya, 2007.

[3] Admosudirjo, Prajudi. Hukum Administrasi Negara. Jakarta: Ghalia Indonesia, 1983.

[4] Wahab, Solichin Abdul. Analisis Kebijaksanaan, dari Formulasi ke Implementasi Kebijakan Negara. Jakarta: Bumi Aksara, 2004.

[5] Agustino, Leo. Dasar-Dasar Kebijakan Publik. Bandung: Alfabeta, 2012.

[6] Khairandy, Ridwan. Pokok-Pokok Hukum Dagang Indonesia. Yogyakarta: FH UII Press, 2013

[7] Hadinoto, Soetanto. Kunci Sukses Bisnis Kredit Mikro. Jakarta: PT. Elex Media Komputindo, 2005.

[8] T. Titik Triwulan and Widodo, Ismu G. Hukum Tata Usaha Negara \& Hukum Acara Peradilan Tata Usaha Negara. Jakarta: Kencana, 2011.

[9] Bohari. Pengawasan Keuangan Negara. Jakarta: Rajawali Press, 1992.

[10] Ivancevich. John, M, et.al. Perilaku dan Manajemen Organisasi. Jakarta: Erlangga, 2008

[11] Harahap, Muhammad Yahya. Hukum Perseroan Terbatas. Jakarta: Sinar Grafik, 2013.

[12] Indonesian Civil Law Code, Kitab Undang-Undang Hukum Perdata

[13] Undang-Undang Nomor 8 Tahun 1999 Tentang Perlindungan Konsumen

[14] Undang-Undang Nomor 24 Tahun 2013 Tentang Administrasi Kependudukan.

[15] Undang-Undang Nomor 14 Tahun 2008 Tentang Keterbukaan Informasi Publik (KIP)

[16] Peraturan Menteri Dalam Negeri Nomor 61 Tahun 2015 Tentang Persyaratan, Ruang Lingkup Dan Tata Cara Pemberian Hak Akses Serta Pemanfaatan Nomor Induk Kependudukan, Data Kependudukan Dan Kartu Tanda Penduduk Elektronik.

[17] Peraturan Menteri Komunikasi dan Informatika Nomor 12 Tahun 2016 Tentang Registrasi Pelanggan Jasa Telekomunikasi.

[18] Peraturan Menteri Komunikasi dan Informatika Nomor 14 Tahun 2017 Tentang Perubahan atas Peraturan Menteri Komunikasi dan Informatika Nomor 12 Tahun 2016 Tentang Registrasi Pelanggan Jasa Telekomunikasi.

[19] Peraturan Menteri Komunikasi dan Informatika Nomor 21 Tahun 2017 Tentang Perubahan kedua atas Peraturan Menteri Komunikasi dan Informatika Nomor 12 Tahun 2017 Tentang Registrasi Pelanggan Jasa Telekomunikasi. 